\title{
A TPACK-in Practice Model for Enhancing EFL Students' Readiness to Teach with Ed-Tech Apps
}

\author{
https://doi.org/10.3991/ijim.v15i17.23465 \\ Agatha Lisa $^{(\bowtie)}$, Abdurrachman Faridi, \\ Dwi Anggani Linggar Bharati, Mursid Saleh \\ Universitas Negeri Semarang, Semarang, Indonesia \\ agathalisa9@gmail.com
}

\begin{abstract}
In Indonesia, educational technology courses have been offered in teacher preparation programs to equip students with theoretical knowledge and practical skill of utilizing technology in skill-based language teaching. Despite this, empirical studies focused on online training for EFL teacher candidates on using digital tools appropriately for pedagogical purposes and adjusting to traditional learning processes remain unexplored. Therefore, to address this gap, the present study attempts to investigate the design and implementation of a TPACK-in practice model to enhance students' preparedness to face the rapidlygrowing digital world and, more importantly, understand post-pandemic pedagogy. For this purpose, a qualitative case study was adopted. The data were obtained from multiple sources, including field notes, video-recorded classroom observation, one-on-one online interviews, and task documentation. The population of this research included 163 students in the 5th semester of the English Language Education Study Program of a university in Yogyakarta, Indonesia. We selected one class randomly, consisting of 40 pre-service English teachers during the odd semester of the 2020/2021 Academic Year. Findings demonstrate: 1) lesson activity-specific model in the educational technology course, 2) students' reports on their hands-on learning experiences in designing teaching-learning activities with a variety of digital tools, 3 ) the perceived benefits of reviewing ed-tech apps, and 4) challenges encountered by students in completing their project. Finally, pedagogical implications are presented with proposed suggestions offered for future research directions in replicating the study.
\end{abstract}

Keywords-TPACK-in practice model, teaching readiness, pre-service English teachers, ed-tech apps for teaching-learning

\section{$1 \quad$ Introduction}

Presently, the rapid advancement of technology has driven English language teaching to be more technology-oriented. It has brought several forms of disruptive innovation, such as the Internet of Things, augmented reality, big data, cloud platforms, and robotics combined with artificial intelligence. These forms of technology have a 
significant impact on the paradigm of the contemporary education sector across the world. For example, computer-assisted language learning (CALL) plays a pivotal role in the world of English language teaching as it could provide hands-on, authentic learning experiences in various ways and by various means [1] "with, though, and around computer technologies (p. 4)" [2]. CALL presents diverse accessibility of information and communication, applications, and teaching approaches, from the traditional drill and practice phase discussed in the 1960s and early 1980s to the new phase of the ecological CALL in the 2010s [3], e.g., as used in the traditional face-to-face classroom instructions, web-based remote learning in virtual worlds and the application of mobile-assisted language learning [4,5].

In the digital era, teaching and learning should be aligned with technological development. Several studies have been conducted under the topic of a new paradigm in the technology-based learning process by the needs of 21 st-century students. The traditional learning model has been considered outdated. With technology, the teaching-learning activities can be made more varied, interactive, fun, and challenging. Indeed, this aspect becomes a challenge and a new opportunity for both pre-service and in-service teachers in contemplating and contextualizing their roles so that they can keep up with the pace of the rapid technological development.

Based on our field observation results, most students have a medium-high level of basic skills in using computers and the internet. They enjoy exploring some evergrowing various apps for learning languages, such as Twitter, readwritethink, TEDTalk, and many others. They also have actively participated in online discussion forums to share and discuss their ideas with peers, classmates, or colleagues. However, the students still lack understanding of how to bring educational apps into teaching. Most of them are enthusiastic about using technology for their future classroom instructions, but they are still confused over selecting the appropriate technology-based learning media. Prior studies have also mentioned that identifying and choosing high-quality instructional apps can be challenging for educators [6-8] since several aspects must be considered, such as curriculum, learning goals, student characteristics, resources, school support, and budget. From another vein, [9] highlighted that living conditions, learning needs, emotional needs, and socio-cultural differences should be considered when leveraging mobile devices for educational purposes.

Therefore, in the last decade, research demonstrated that developing educational app evaluation rubrics is essential for supporting teachers' selection of appropriate educational apps [10-13]. The accuracy in learning media selection influences the learning-teaching effectiveness and students' achievement. Indirectly, it could improve more students' engagement in the learning process. Accordingly, one way to overcome the problems mentioned above is providing workshop sessions, where EFL students can learn how to appropriately choose and effectively use the functionalities of educational technologies for enjoyable yet meaningful teaching-learning practices. In addressing these demands, in the context of ELT, comprehensive training, teacher preparation programs, the short-and-long-term professional development models, seminars, and workshops in ICT have gained much attention in the existing literature to improve TPACK skills. 
Several studies have reported on the improvement of pre-service English teachers' TPACK through various activities, such as instructional model [14], long-term ELT program [15], ADDIE model [16], and workshop sessions [17]. However, specific online learning-teaching activities to train EFL teacher candidates to use digital tools appropriately and effectively for fieldwork teaching experiences and adjust traditional learning processes are not yet well-reported and explored, specifically during the COVID-19 pandemic period. Therefore, to bridge this gap, this study aimed to investigate the design and implementation of a TPACK-in practice model for enhancing students' readiness to teach with technology. Specifically, participants will learn how to combine and connect their technological knowledge, content knowledge, and pedagogical knowledge for online teaching practices. Our four research questions of the study were as follows:

1. How was the design of the TPACK-in practice model implemented in the educational technology course?

2. How did the students perceive the hands-on learning experiences in designing teaching-learning activities with various digital tools?

3. What were students' perceived benefits when executing their project task of evaluating ed-tech apps for pedagogical purposes?

4. What challenges were encountered by the students when executing their project task of evaluating ed-tech apps for pedagogical purposes?

\section{Literature review}

This section describes some critical concepts and elaborates relevant theoretical foundations to framing the present study. It explores several learning theories covering the TPACK-in practice model, ed-tech apps for teaching-learning activities, and teacher education programs.

\subsection{TPACK-in practice model}

The lens of the TPACK framework guided this study. The epistemology of the TPACK framework has been a clear perspective for many current professional teacher education programs, which have experienced a significant learning paradigm shift in making technology a transformative part of the education field. This model was developed by [18] from [19-20]'s conceptualization of Pedagogical Content Knowledge. Researchers commonly define the theoretical definition of TPACK as essential knowledge, which consists of seven knowledge types, namely Technology Knowledge (TK), Content Knowledge (CK), Pedagogical Knowledge (PK), and the intersection of these knowledge types (TPK, TCK, PCK). Conceptually, the heart of the TPACK framework is the knowledge in the center, that is, teachers' knowledge relating to the use of ICT tools with appropriate pedagogical methods and strategies when teaching certain subject matter contents. Following this popular framework, teachers have to understand digital media, Web 2.0 tools best suited with the areas of pedagogy - "how 
to teach" and the content - "what to teach" to accomplish fruitful teaching. However, in educational technology researches, the TPACK framework has been criticized by some researchers for its lack of conceptual definition and specificity constructs viewed from integrative and transformative views [21] and the "Goldilocks Principle" [22]. [23] Furthermore, [24] have argued that the model of TPACK has "fuzzy boundaries"; thus, it is challenging to classify borderline cases. Related to these issues, [25] argued that the TPACK framework "does not illuminate what the theoretical constructs might look like in practice (p. 139)." Therefore, they developed the TPACK-in Practice model (see Figure 1) to fill the gap between knowledge and its implementation. The empirical research results found that the proposed model provided teachers with various activity types following content-related learning needs and teaching models, thus successfully building up teachers' professional knowledge development for teaching with educational technologies.

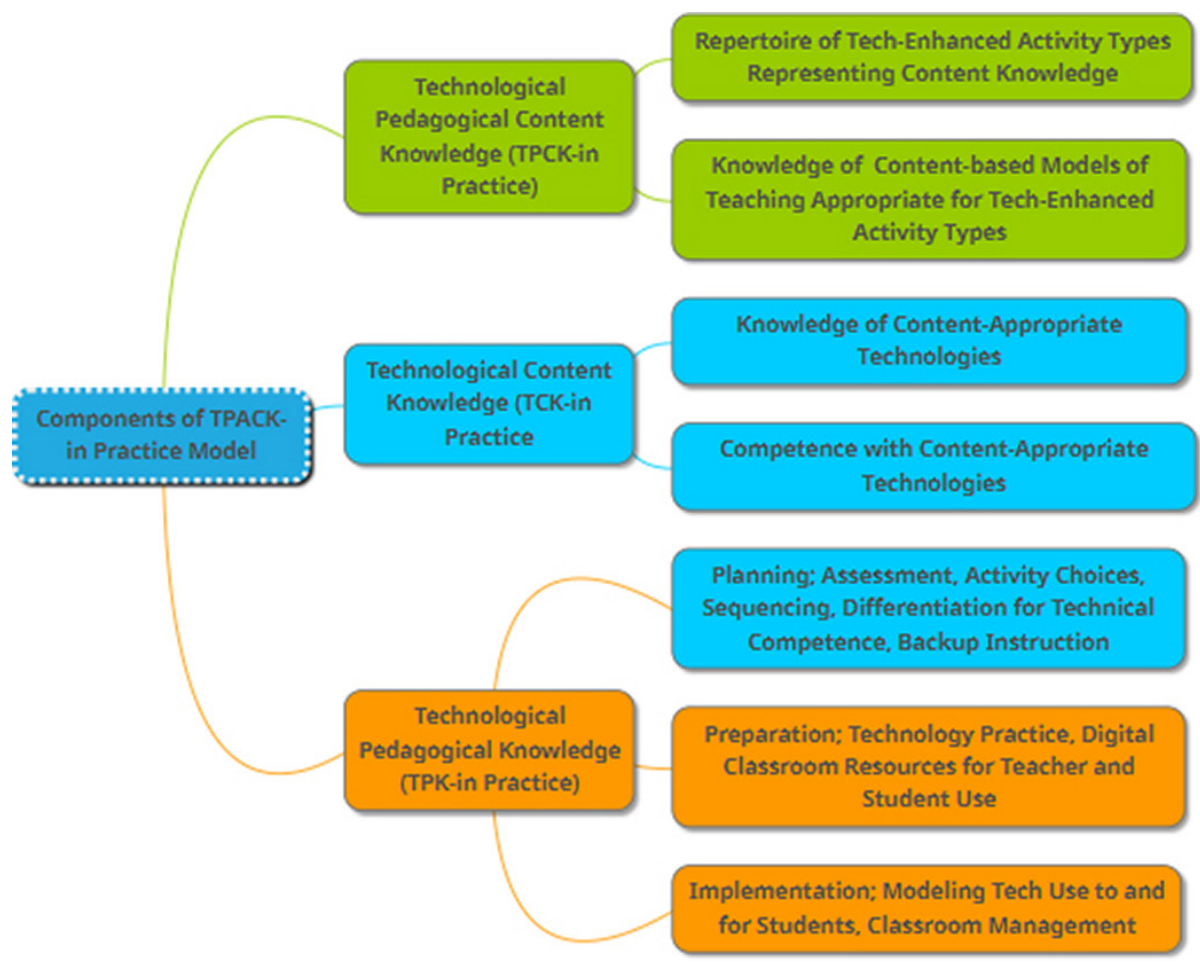

Fig. 1. TPACK-in practice framework [25]

In the current study, this TPACK-in Practice framework was grounded in the language lecturers' capability to design an instruction model, including the range of methods and techniques of how courses are delivered, where students are equipped with theoretical and practical knowledge of how to incorporate technology in skill-based language teaching as well as building their ability to be lifelong learners. As prospective teachers in the future, EFL students must have much-needed digital competence, skills, and knowledge. They need to be nurtured in mastering various technological tools, 
which are then used at various levels as supporting media for teaching students of Generations Z, Alpha, and beyond. As such, [26] pointed out that gaining "strong knowledge" in the seven domains of TPACK can determine student teachers' success in the teaching-learning process in the classroom. Interestingly, [27] found that prospective teachers with high mean scores in TPACK areas have better teaching performances than those who have low mean scores on the perceived knowledge. Contrary to these findings, [28] reported that the mean scores of TPACK and students' academic achievement have no significant relationship.

\subsection{Ed-tech apps for teaching-learning activities}

In recent years, numerous mobile applications, websites, and platforms are available for free in Google Play Store, App Store (iOS), or websites. Most of them have been well-developed, tested, and highly accepted for pedagogical purposes; to facilitate students' learning, design learning materials, support teaching interactions, discussion, and assessment [29-30]. Consequently, the use of digital tools in language teaching and learning has widely expanded. A growing number of empirical studies have revealed that the utilization of technology in instructional practices offers benefits for students' academic pursuits, for instance, improving writing performance [31], reading comprehension [32], listening [33], speaking [34-35], grammar accuracy [36-37], vocabulary acquisition [38-39], as well as boosting students' engagement [40], motivation [41], and autonomous learning [42]. However, previous ELT studies highlighted that educational technology could successfully support students' learning when it is adequately well-integrated into the classroom practices [43] and more importantly, it fits learning goals and students' current needs. A step-by-step guideline for in-service and pre-service English teachers to select and use various learning platforms/tools in delivering virtual lessons is needed for this to happen.

In today's situation, when the COVID-19 pandemic has been declared as a community health emergence by WHO, digital tools can contribute significantly to facilitating remote learning. The affordances of user-friendly virtual video communication tools (e.g., Google Meet, Zoom, WebEx), collaboration platforms (e.g., Google Docs, Google Classroom, Issuu), and social media (e.g., Instagram, YouTube, EdPuzzle) can expand interactions among teachers and students beyond the classroom walls. Using technology, we can let students set their learning goals, make plans, and monitor their progress. Several studies have shown that digital media are strongly aligned with students' self-paced and self-directed learning to learn independently in their pace and space [44-46].

\subsection{Pre-service teacher education; enhancing teaching readiness in the digital age and post-pandemic pedagogy}

In teaching-learning, we have been familiar with the shift from the notion of teachers' knowledge authority - the content/subject disciplinary experts of the classroom, facilitator of learning - facilitating the learning process of the students to individual teachers as designers of learning experiences in a specific environment for students being "experts in the art and science of teaching (p. 20)" [46]. In today's digital age, 
what does it mean to be a designer of learning? Teachers take on the role of designer of learning with synchronous and asynchronous technologies. As designers, they should have some considerations (e.g., knowledge representations, pedagogic relations, organization of learning) in selecting the right EdTech tools (e.g., Edmodo, Quizlet, Padlet, TED-talks). They should be able to facilitate the desired learning goals of the lesson and, more importantly, understanding the value of technology that can potentially change the way of teaching language in the classroom. They have to be aware of what they can and cannot do when using technologies and are mindful of using them effectively and appropriately.

Government policies of physical and social distancing during unforeseen pandemic situations significantly impact the education system. Face-to-face schooling has been stopped temporarily and shifted to the teaching-learning process orchestrated in online mode to reduce physical contact and thereby minimize the widespread of COVID-19 transmission. Therefore, the Indonesian Ministry of Education and Culture began to plan, prepare, shape, and hone nationwide experiments of wholly online instruction. All learning was moved from the classroom to the online space, adjusting to L2 curriculum, media, assessment during emergency remote learning. In reality, the sudden pedagogy transition poses some challenges and multiple barriers, such as online teaching readiness and preparation, pedagogical changes, course delivery problems, class disruptions due to a slow internet connection, students' personal growth, social presence, and cybersecurity [47-48].

By and large, prospective teachers need basic knowledge of successful technology integration in the 21 st-century classroom and post-pandemic world. Hence, fostering student teachers' professional knowledge and competence in designing learning-teaching with technology becomes an essential element for teaching preparation in the field and improving the quality and efficiency of the Indonesian education agenda. Some free sessions of practical training and workshops are needed to guide the pre-service teacher in facing the new teaching-learning paradigm. As professional teachers, they have to adapt to students' needs, interests, and conditions.

\section{Method}

The following sub-sections present the research design, context, participants, instruments, data collection procedures, and data analysis.

\subsection{Research design}

The study employed a qualitative case study research design to answer the four research questions. [49] states that a case study is a research design that uses multiple types of ethnographic data from various sources. Hence, it allows the researchers to maintain a holistic and real-world perspective in studying and understanding single or multiple cases comprehensively in the complex social phenomena of the practicing profession, including education [50-51]. Therefore, concerning the context of language education, this study examines the whole learning-teaching activities thoroughly while implementing a TPACK-in practice model for advancing students' readiness to teach with technology. 


\subsection{Research context and participant}

This study was conducted in an elective educational technology course called Computer-Assisted Language Learning EEDU 108. This course was provided in the odd semester of the 2020/2021 Academic Year. Each week, students had to attend the class. The population of this research was 163 students from the 5th semester of the English Education Study Program of a university in Yogyakarta, Indonesia. We took one selected class randomly, consisting of 40 pre-service English teachers with different GPAs, diverse cultural backgrounds, geographic areas, and varied field experiences. More specifically, the average GPA was 3.49. In terms of gender profile, $67 \%$ of participants $(\mathrm{n}=27)$ were female and $33 \%$ were male $(\mathrm{n}=13)$. Twenty-six students were between 16 and 20 years old in terms of the age range, thirteen students were between 21 and 25 years old, and one student was over 26 years old. The average age was $20(\mathrm{SD}=$ 1.494). All the participants were third-year undergraduate students who had passed some prerequisites courses, including Learning Teaching Media EEDU 102, Language Learning Assessment EEDU 103, Learning Program Design EEDU 104, Educational Management PKGF 104, Approaches, Methods, and Methods Techniques EEDU 101. All the students agreed to participate in this research project after signing an informed consent letter and receiving a voucher as a gift for their participation. Also, the request for permission to conduct the present study was approved by the vice-rector for academic affairs of the university last year. All participants followed four phases during the online workshop (Figure 2). The lecturer introduced the theoretical foundations of utilizing ed-tech apps for language learning and the TPACK framework in the first phase. In the second phase, the participant explored to find apps. Then, they practiced reviewing a digital application for learning. They were asked to list the things to consider in reviewing, such as introduction, user experience, technical information, limitations of the apps, and references. Finally, they designed a technology-enriched English lesson plan. For example, the participant applied the Quizizz app for a grammar class or the EdPuzzle app in a listening lesson.

\begin{tabular}{|l|}
\hline \multicolumn{1}{|c|}{ First phase: Start! } \\
\hline Second phase: Explore! (TK, TPK, TCK) \\
\hline Introduce ed-tech apps for language learning and TPACK framework. \\
\hline Find apps that can be utilized in EFL learning. \\
\hline \multicolumn{2}{|c|}{ Third phase: Practice! (TK, CK, PK, TCK, TPK, PCK) } \\
\hline $\begin{array}{l}\text { Review a digital application for learning (introduction, user experience, technical } \\
\text { information, limitations of the apps, references). }\end{array}$ \\
\hline \multicolumn{2}{|c|}{ Fourth phase: Apply! (TRACK) } \\
\hline $\begin{array}{l}\text { Design a technology-enriched English lesson plan (teaching activities in specific } \\
\text { content). }\end{array}$
\end{tabular}

Fig. 2. Structure of TPACK-in practice model in the present study 


\subsection{Instruments and data collection procedures}

Multiple sources and data collection methods such as video-recorded classroom observation, field notes, one-on-one online interviews, and task documentation were used as research instruments. First, we purposely designed a guideline for field notes and a classroom observation scheme during the workshop session. It was comprised of five key dimensions of learning: content (what), context (where), characteristics of students (who), temporal element (when), and reason (why). Equally, these aspects were beneficial for us to record what we saw and wrote notes for what happened during the whole lesson observation, including classroom clarity and organization, instructional demands and supports, lecturer-students interaction, and students' participation. Second, we collected 40 task documentation - video assignments projects relating to apps for learning a language. Finally, we intentionally selected eleven interviewees purposively. Each interview was conducted for about 15 minutes. Four main questions, which start with "How...?", were designed as the interview protocol. The one-on-one interview schedules were set based on the agreement between the researchers and the participants. It was conducted online through the Zoom meeting app to elicit in-depth exploration of pre-service teachers' perceptions and gain detailed information about their experiences from participating in the online workshop.

\subsection{Data analysis}

The interviews were logged and video-recorded, then transcribed for qualitative analysis. For ensuring trustworthiness and qualitative data validity/credibility, we used the concept of member checking and "critical friend." The first author analyzed the narrative text, and three co-authors double-checked the research results. Then, the participants were asked to read the interview transcriptions for confirmation and the interpretation results for clarification. We also offered participants who wanted to add additional information and perspectives. The grounded theory approach [52-53] was adopted for collecting large amounts of interview transcripts, sorting data, displaying data chunks, identifying categories during the coding scheme, generating global themes, and analyzing the trends of task documentation. In applying the first cycle of the coding process, we followed the steps in vivo coding method [54]. First, we used the data record of excerpts such as words, phrases, or sentences from the participants' voices during the one-on-one interview session. Then, we summarized all the data segments. In the second cycle, we grouped those summaries into several categories and sub-categories based on relevance to the research questions. In displaying and discussing the data, we used the most frequent codes. For example, one respondent-PSET09' "...to do many rehearsals to minimize speech production errors, such as pronunciation, speed, self-repetitions, accent, filled pauses, and intonation in completing his project" comment was coded language fluency. This coded was categorized as participant's challenges; therefore, we determined it as a pedagogical challenges pattern. Finally, we checked all the patterns in code lists "whether they have some conceptual and structural unity (p. 87)" [54]. 


\section{$4 \quad$ Findings and discussion}

The overarching purpose of this present study is to explore the design and the implementation of a TPACK-in practice model for advancing students' readiness to teach with technology. Significant findings presented in this section include: 1) lesson activity-specific model in the educational technology course, 2) students' reports on their hands-on learning experiences in designing teaching-learning activities with a variety of digital tools, 3) the perceived benefits of reviewing ed-tech apps, and 4) challenges encountered by students in completing their project. The discussions are expanded as follows.

\subsection{Learning-teaching activities in educational technology course}

Research Question 1: How was the design of the TPACK-in practice model implemented in the educational technology course?

The theme of the online workshop in the 6th meeting was selecting appropriate ed-tech apps for learning a language. It was held through the Zoom meeting app and Telegram Group. At the end of this workshop session, the students were required to make a 5-10-minute video. The video should contain the review of application which can be used in the teaching-learning process. The students are free to select the application that they want to review. There are themes which can be used for students as a guideline to finish their work: a) introduction (the background - reasons why they choose the digital tool and brief introduction to tell the viewers on how the apps works, b) user experience (the way of the content is presented, the application display, and accessibility), c) language learning (the learners' language practice, tracking learning, and interaction. The language practice is divided into three main points. They are language skills and knowledge, learner control, and the effectiveness of teaching large classes. The tracking learning pinpoints learning goals and assessment. The interaction covers communication and collaboration for sharing the idea), d) technical information (the information related to the internet connection, storage usage, data usage, and user support), e) limitations (the limitations of using the app), f) references (the list of references that the students used in doing the review. The references can be taken from a research article, websites, or books), g) format (the review will be delivered in the form of a video. The students should give interesting captions in the description box, background music, photos, diagrams, graphs, visuals, or any other artwork to grasp viewers' attention), and $\mathrm{h}$ ) video duration. The duration for the completion of this assignment is two weeks. After the video has been completed, it should be uploaded to students' YouTube channel, and the link of the video should be submitted to the LMS.

Video-making activities have recently been more accessible. The students may use numerous applications in recording and editing videos provided for free on the internet, such as Screen-O-Matic, Bandicam, FlashBack, V Recorder, Camtasia, Avs4you PowerDirector, Wondershare Filmmora, InShot, and Film Maker. From 40 videos that have been submitted, there are 28 applications that the pre-service English teachers selected. Without having a purpose of endorsing particular digital media for teaching, 
we provide a brief description of some cloud applications that could bridge students' knowledge gap. The results are presented in Table 1. The students have reviewed the apps based on the subject matter, free/paid/premium, and online/offline.

Table 1. List of cloud applications for learning languages; student reviews

\begin{tabular}{|c|c|c|c|}
\hline Name & Subject Matter & $\begin{array}{l}\text { Free/Paid/ } \\
\text { Premium }\end{array}$ & $\begin{array}{l}\text { Online/ } \\
\text { Offline }\end{array}$ \\
\hline Anchor & Listening, Speaking & Free & Online \\
\hline Audacity & Speaking & Free & Offline \\
\hline Babbel & Speaking, Grammar, Vocabulary & Free, Paid & Online \\
\hline Busuu & $\begin{array}{l}\text { Reading, Listening, } \\
\text { Writing, Speaking }\end{array}$ & Free, Paid & $\begin{array}{l}\text { Online, } \\
\text { Offline }\end{array}$ \\
\hline Cake & Speaking, Listening, Grammar, Reading & Free & Online \\
\hline Duolingo & Listening, Speaking, Reading, Writing & Free, Paid & $\begin{array}{l}\text { Online, } \\
\text { Offline }\end{array}$ \\
\hline Edmodo & Reading and Writing & Free & Online \\
\hline EdPuzzle & Listening & Free, Premium & Online \\
\hline Grammar & Grammar & Free, Paid & Offline \\
\hline Instagram & $\begin{array}{l}\text { Pronunciation, } \\
\text { Vocabulary, Writing }\end{array}$ & Free & Online \\
\hline Liveworksheet & Vocabulary and Grammar & Free, Premium & Online \\
\hline Mango language & Listening, Speaking, Reading, Culture & Free, Paid & Online \\
\hline Memrise & Listening, Grammar, Pronunciation & Free, Premium & Online \\
\hline Pixton Comic Maker & Writing & $\begin{array}{l}\text { Free, } \\
\text { Premium }\end{array}$ & Online \\
\hline PowToon & Listening, Speaking & Free & Online \\
\hline Quipper & Reading, Listening & Free & Online \\
\hline Quizlet & Vocabulary, Grammar, Reading, Listening & Free & Online \\
\hline Rosetta Stone & Pronunciation, Listening, Vocabulary, Grammar & Free, Paid & $\begin{array}{l}\text { Online, } \\
\text { Offline }\end{array}$ \\
\hline Socrative & Vocabulary, Grammar & $\begin{array}{l}\text { Free, } \\
\text { Premium }\end{array}$ & Online \\
\hline Spotify & Listening, Vocabulary & $\begin{array}{l}\text { Free, } \\
\text { Premium }\end{array}$ & Online \\
\hline Talk & Listening, Speaking & Free, Paid & Online \\
\hline TED & Listening & Free & $\begin{array}{l}\text { Online, } \\
\text { Offline }\end{array}$ \\
\hline TikTok & Speaking, Listening & Free, Paid & Online \\
\hline Twitter & Reading, Writing & Free & Online \\
\hline U Dictionary & $\begin{array}{l}\text { Vocabulary, } \\
\text { Pronunciation, Listening }\end{array}$ & Free, Paid & Online \\
\hline Wattpad & Reading, Writing & Free, Premium & $\begin{array}{l}\text { Online, } \\
\text { Offline }\end{array}$ \\
\hline Wordscapes & Vocabulary & Free, Paid & Online \\
\hline Wordwall & Reading, Vocabulary, Grammar & Free, Premium & Online \\
\hline
\end{tabular}


Table 1 explicitly presents a list of applications employed in learning-teaching activities to improve various language skills and knowledge, such as reading, writing, speaking, listening, pronunciation, vocabulary, and grammar. The apps can be accessed online, offline, or both. More interestingly, some applications provided preliminary tests in order to define the user's language proficiency level. Therefore, they can adjust themselves to the difficulty level in the subsequent learning stage. However, some apps require the users to spend extra funds in order to afford the exclusive features. In order to purchase the complete version of the applications, the users can afford them through Google Play Store, App Store (iOS), or web.
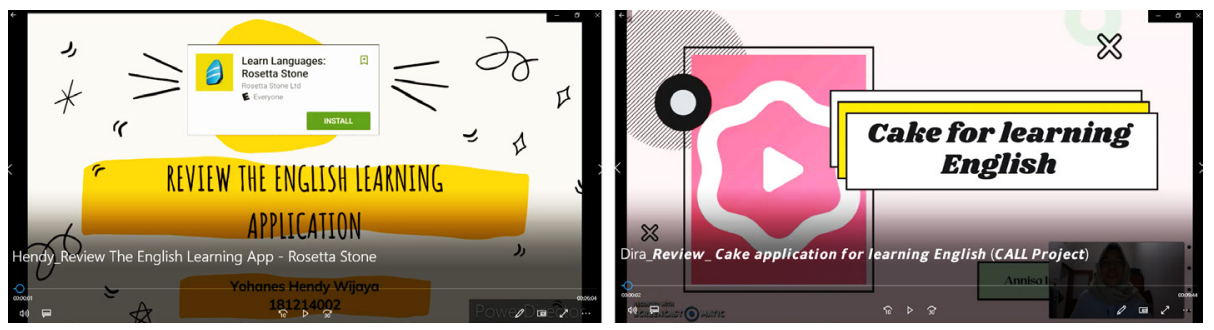

Fig. 3. Screenshot of students' task documentation

\subsection{Designing teaching-learning scenarios: student experiences}

Research Question 2: How did the students perceive the hands-on learning experiences in designing teaching-learning activities with various digital tools?

The current focus of teacher education programs is designing a teaching module that provides meaningful learning experiences for prospective teachers who will teach Gen $\mathrm{Z}$ students. Therefore, in this section, we briefly present two examples of the students' work concerning utilizing the ed-tech apps for the language learning-teaching process. Later, they will use their teaching-learning scenario design for teaching practices in Micro Teaching EEDU 105 course next semester. The two examples selected from the results of the students' app reviews are Spotify and Wattpad.

The first application is Spotify. It is a user-friendly and easy-access application that can be utilized for all students with various competency levels. This application will invite students to have valuable experiences in leveraging their knowledge and learning needs. It can boost students' listening skills [55] or improve their speaking skills. The teacher can use it for pedagogical purposes, for example, the use of podcasts. The portable digital audio files can be used for listening practices multiple times and pausing to allow the students to process the information. The teacher can use that feature for language learning through the following steps. First, choose a specific topic and determine the level based on the students' skills. The teacher can discover and stream various categories (educational, technology, health, culture, lifestyles, arts, and entertainment) and artists worldwide. Then, guided questions are presented while the students are listening to the podcast. After that, the students discuss their answers with their peers or small group. As the follow-up assignment, the teacher can invite the students to make their 
podcasts using Anchor App. They can edit their audio by visiting Sound-trap provided by the app. Finally, they can publish their project to Spotify. To make it easier to be recognized by others, they have to make an eye-catching title and provide some hashtags.

The second application is a social platform for connecting creative writers and readers worldwide, namely Wattpad. It is a top-rated educational platform that can improve students' literacy by reading tons of popular stories, novels, and e-books and writing their own stories [56], [57]. This storytelling app is suitable for students who are members of the Millennial and $\mathrm{Z}$ generations. Various genres, such as historical, science, romance, adventure, and action writing, with numerous foremost trending titles, help the students upgrade their knowledge and craft their writing ideas. The steps for bringing this digital tool into language teaching are as follows; a) introduction - get to know the app, b) exploration - choose and read some stories, c) implementation - start the writing journey by outlining and developing students' own stories, and d) publication. At the end of the class session, the students share and publish their work on that platform. Then, the teacher and other students can give feedback and comments. Additionally, this app can be designed for individual or group work projects, depending on the students' needs and class size.

\subsection{Students' perceived benefits in evaluating ed-tech apps}

Research Question 3: What were students' perceived benefits when executing their project task of evaluating ed-tech apps for pedagogical purposes?

From the interview results with 11 pre-service English teachers, four perceived benefits were obtained from the findings. They were techno-pedagogical content knowledge, creativity, autonomous learning, and critical thinking.

Techno-pedagogical content knowledge. The first perceived benefit was technopedagogical content knowledge. This notion referred to pre-service teachers' ability to understand how to choose, utilize, or design digital learning tools successfully and meaningfully for instructional practices. Therefore, the workshop sessions in this study provided students with the fundamental knowledge and actions to practice the knowledge. It would be beneficial for students' teaching practicum in the field next semester. One respondent mentioned that she could choose an app for various learning activities, such as speaking, listening, reading, and grammar.

I learned a lot after joining the workshop session and did the task [reviewing ed-tech apps]. Previously, I do not know how to choose appropriate teaching-learning media for [example] assessing students, enhancing collaboration, encouraging students' learning in and outside the classroom, and many others aspects. I enjoyed all the workshop sessions this semester. Also, the lecturer provided clear guidelines to review apps/websites/ educational platforms before we use them for teaching. I cannot wait to implement the application that I have reviewed in the following semester [teaching practicum in the field]. At that time, I choose one application for listening, speaking, grammar, and reading activities. To promote students' collaboration, I use a collaborative learning approach (PSET09 31 January 2021). 
Creativity. The second perceived benefit was creativity. Concerning this aspect, two pre-service English teachers mentioned that video creation could potentially improve their creativity. This creativity referred to their skills in delivering their app review in the form of video uploaded on their YouTube channel. In this sense, their roles were as content creators and performers. Hence, they deal with creative video concepts to make their videos more attractive, such as adding background music, fashion images, animation, visuals, text, or any other artwork as a crucial aspect to maintain viewers' engagement.

In my opinion, I can improve my creativity by completing the video-making assignment. Whether I realize it or not, I think about the concept, background, animation, music, and even video sounds quality (PSET05 - 26 January 2021).

I should ensure that my video's quality is good, with interesting concepts and layout, and many others since I will upload it to my YouTube channel, submit the link to the LMS, and share it with my lecturer and friends. The video will be set in a public mode to access and view (PSET10 - 29 January 2021).

Autonomous learning. The third perceived benefit was autonomous learning. Stimulating students to be independent learners would be beneficial for them since they will be professional teachers shortly. Therefore, the current project's design encouraged the students to take their decision-making and responsibility by giving them the freedom to select applications they want to evaluate. Then, they could design and adjust their video content materials according to their ability, interest, learning strategies, and imagination. Indeed, it posed a challenge and a new opportunity for the teacher candidates to execute their targeted assignment properly.

Since I have to do a review, it means that I need to browse much information so that the review results will be good. As a teacher [in the future], I have to review the application and consider whether the application is suitable for the teaching activities (PSET11 - 31 January 2021).

We do learn independently since we choose the apps freely. The lecturer gives us freedom. [Therefore,] we should find information before we do the review. Unfortunately, there is a theory that I have not understood well, but then I can ask my friends or my lecturer. Besides, I can start looking for some information on my own. Then, for the concept of presenting the review in the form of a video, I browse some models on YouTube. For example, I can get the idea for making an eye-catching video opening and closing (PSET01 - 16 January 2021).

Critical thinking. The fourth perceived benefit was critical thinking. This area referred to the students' thinking to critically find the educational apps' strengths and weaknesses. The students had to pay attention to several important points in evaluating the app quality for teaching practices, such as application display, accessibility, language practice, tracking learning, and technical information. To do so, they were required to find and read some related references in the current literature repository to support their 
ideas and arguments. Besides that, by uploading videos on YouTube, the students could get constructive feedback and critical comments from the lecturer and classmates.

In this review assignment, we have to explain the strengths and weaknesses of the application. The lecturer outlines her direction for finding the list of references. Therefore, we start looking for the information through the journals or the websites that support our argument (PSET07 - 27 January 2021).

\subsection{Challenges encountered by students in completing their project}

Research Question 4: What challenges were encountered by the students when executing their project task of evaluating ed-tech apps for pedagogical purposes?

The process of reviewing the educational applications and presenting them in the form of a video was not an easy task. Six students mentioned the problems and challenges in finishing the project. Their statements could be found in the following excerpts taken from the results of the one-on-one interview session. This section discusses two themes that were identified, namely pedagogical and technical challenges. They were revealed by the analysis and presented in an interpretative manner.

Pedagogical challenges. The first theme was related to pedagogical challenges. It was divided into five challenges. The first challenge was concerning students' selfconfidence level, which is related to students' trust and belief in their capability to do things successfully. Unfortunately, the respondent revealed that she lacked confidence in using educational technologies. She further acknowledged that it was her most significant barrier in the learning process. She found difficulties in elaborating her conceptual ideas. As a result, it could demotivate her to complete the task.

I am not confident with the presence of technological development itself. As a result, I still have to adjust myself whenever I get techno-related assignments. Indeed, I still have difficulties completing it lapp review in the form of a video] ... (PSET02 - 21 January 2021).

The second challenge was dealing with language fluency. Fluency pertained to students' linguistic delivery smoothly and efficiently. In general, it could be considered as respondents' spoken language proficiency. In this context, they were pushed to perform well in public by sharing their task on the online educational platform. Hence, the task reinforced students to train their speaking skills. One respondent mentioned that he had to do many rehearsals to minimize speech production errors, such as pronunciation, speed, self-repetitions, accent, filled pauses, and intonation. He practiced how sounds were pronounced using the proper intonation.

I should do many rehearsals, especially for the video-recording part. At the same time, I should ensure whether my intonation and pronunciation have been appropriate and my facial expression has already been perfect (PSET09 - 27 January 2021). 
The third challenge was time management. It was regarded as the pre-service teacher's ability to determine their timelines to finish the task on time systematically. This kind of video creation presents information to viewers. It involved several stages of preparation, including outlining draft, installing apps, recording and editing video content, consulting with the lecturer, uploading the video on YouTube channel, writing an exciting caption, and giving comments on other friends' works (to get extra scores on participation). As a third-year undergraduate student, she started to take a part-time job. Therefore, she worried about time arrangements for completing different course assignments, other activities, and field problems.

At the same time, I should manage my time well since I have been studying and working. This assignment takes a long time, spanning from the planning until the uploading of the video to YouTube (PSET02 - 21 January 2021).

The fourth challenge was app selection. With thousands of educational platforms, applications, and websites available, the students were required to choose one app to be evaluated. Therefore, the student revealed that she was confused in deciding which app to evaluate. She was also worried if the app that she selected had been evaluated by her friends.

She [the lecturer] does not provide a list of the applications that can be reviewed. So, we are provided with complete freedom over this assignment. As a result, [for me] I am confused about deciding which application I should review since many applications are available on the Internet, Apps Store, or Play Store. At the same time, I am also afraid if the application that I have selected turns out to have been reviewed by my friends (PSET03 23 January 2021).

The last challenge was the learning adaptability struggle. It formally referred to students' ability to cope with new, changing, and challenging learning situations. Due to the current condition of the COVID-19 pandemic, teaching and learning have shifted from face-to-face to online mode. Although the university has started to implement blended learning, still remote learning is a new learning model for respondents. Therefore, the implementation of online learning presented challenges for some students. One respondent mentioned that she could not directly ask any questions to understand the assignments. She hesitated to send a message to the lecturer.

I want to consult with the lecturer before uploading it, but I am afraid our class is online [due to a pandemic situation]. I am worried that the lecturer is still teaching or working on her other assignments. If we are in the classroom [face-to-face], we only raise our hand whenever we have questions or difficulties (PSET04 - 23 January 2021).

Technical challenges. The second theme was related to technical challenges, which are internet connection and apps availability. The first challenge was an internet 
connection. It is closely related to Indonesia's geographical condition, which is very wide and consists of thousand islands. The respondents lived in different islands and provinces; Jawa, Bali, Kalimantan, and Sumatra. Unequal distribution of electricity and unstable internet connection caused many troubles in the learning process. A student living far from the city revealed that he failed to upload his task due to internet connection shortages.

I have to rely on the tethering feature from my smartphone. Therefore, uploading the video to YouTube takes a long time. The other problem is a bad internet connection. I do not live in a city. The saddest part is that the uploading process reached $99 \%$, but it failed due to the unstable signal (PSET06 - 26 January 2021).

The second challenge was technology cost. The growth of digital tools in education can facilitate students' ease of video creation. Professional editing tools such as Wondershare Filmmora, Camtasia, and Adobe Premiere can add text, colors, background music, inserting graphic images, and animation. However, some of them are commercial versions. One respondent said that the free version had limited features and some video watermarks.

There are free and pro versions of video-editing applications. If we use the free version of the video-editing applications, such as Wondershare Filmmora, there will be a watermark on the video after saving it. As a result, we should turn to the pro version if we do not want to have the watermark on our video. I hope that the university provides this facility for us (PSET08 - 27 January 2021).

The results of this current study prove that the TPACK-in-practice model has many positive impacts on students' techno-pedagogical knowledge and other aspects, such as creativity, critical thinking, and autonomous learning. These findings align with previous empirical research results, such as [25], who found that the model successfully promotes teachers' professional knowledge development for teaching with educational technologies. Furthermore, data show that the participants systematically evaluate the ease, efficacy, and efficiency of apps for creating practical skill-based language classroom activities. This learning step plays a fundamental and supportive role in nurturing students' preparedness and readiness to teach remotely with a wide range of interactive ICT tools. As qualified, knowledgeable, and thoughtful educators, student teachers must understand that integrating digital applications for classroom practices should be applicable, age-appropriate, meaningful, and appealing [58]. More crucially, they should be able to choose apps that could provide students with good opportunities to be cognitively engaged in real-world contexts and support the development of students' Computational Thinking (CT) along with Computational Fluency (CF) [59]. Briefly, apps selection needs to be considered carefully before the actual teaching practices, especially when designing ICT-implemented instructions. 


\section{Conclusion}

This qualitative case study explored the design and implementation of the TPACK-in practice model for enhancing EFL students' readiness to teach with ed-tech apps. We used qualitative data to examine the construct of lesson activity-specific model, explore students' reports on their hands-on learning experiences in designing teaching-learning activities with various digital tools, and how a group of pre-service English teachers perceived benefits and encounter challenges online training the COVID-19 pandemic. The lesson activity-specific model produced positive results since it contributes to the students' techno-pedagogical knowledge, creativity, autonomous learning, and critical thinking. The participants were able to design technology-enriched English lesson plans. These aspects are equally essential to be mastered by the students who want to be professional teachers in the 21 st-century classroom and post-pandemic world. Regarding the pedagogical and technical challenges, some students struggled in facing difficulties during project completion. These areas become a clear focal point that EFL teacher training needs to schedule individual consultation outside the workshop sessions to assist the students.

Concerning the strengths of the present study, we have shown that the qualitative data used could be measured in a reasonable, consistent, valid, and reliable manner. In addition, the qualitative data were accurate to the implementation of emergency remote training since the data were obtained in real-time during the pandemic. However, we cannot generalize the research findings due to the small number of participants and the highly contextualized nature. Nevertheless, despite the small sample research size, we could identify helpful and in-depth information. Through qualitative findings, we expand prior conceptualizations of the TPACK-in practice model. The present study's limitation proposes future research opportunities. Future researchers can expand the number of the sample and add quantitative data. Findings from this study can provide significant contributions to the body of the literature review. They could enrich the exploration of online lesson activity-specific models in the educational technology course, whereas previous studies have focused on face-to-face training models in general. Furthermore, the current study results could also be used to consider teacher education programs, stakeholders, education boards who want to provide some practical training sessions, mini-workshops, and courses to prepare pre-service teachers' teaching readiness.

\section{References}

[1] Otto, S. E. K. (2017). From past to present a hundred years of technology for L2 learning. In C. A. Chapelle, \& S. Sauro (Eds.), The Handbook of Technology and Second Language Teaching and Learning, (pp. 11-25). WILEY Blackwell. https://doi.org/10.1002/9781118914069.ch2

[2] Egbert, J. L. (2005). Conducting research on CALL. In J. L. Egbert, \& G. M. Petrie (Eds.), CALL Research Perspectives, (pp. 3-8). Routledge. https://doi.org/10.4324/9781410613578

[3] Chun, D. M. (2019). Current and future directions in TELL. Educational Technology \& Society, 22(2), 14-25. 
[4] Al-Ahdal, A. A. M. H., \& Alharbi, M. A. (2021). MALL in collaborative learning as a vocabulary-enhancing tool for EFL learners: A study across two universities in Saudi Arabia. SAGE Open, 1-9. https://doi.org/10.1177/2158244021999062

[5] Wu, J. G., \& Miller, L. (2020). Improving English learners' speaking through mobile-assisted peer feedback. RELC Journal, 51(1), 168-178. https://doi.org/10.1177/0033688219895335

[6] Kolak, J., Norgate, S. H., Monaghan, P., \& Taylor, G. (2020). Developing evaluation tools for assessing the educational potential of apps for preschool children in the UK. Journal of Children and Media, 1-21. https://doi.org/10.1080/17482798.2020.1844776

[7] Papadakis, S., Kalogiannakis, M., \& Zaranis, N. (2018). Educational Apps from the Android Google Play for Greek preschoolers: A systematic review. Computers \& Education, 116, 139-160. https://doi.org/10.1016/j.compedu.2017.09.007

[8] Cherner, T., Lee, C-Y., Fegely, A., \& Santaniello, L. (2016). A detailed rubric for assessing the quality of teacher resource apps (EJ1106773). ERIC. http://www.jite.org/documents/ Vol15/JITEv15IIPp117-143Cherner2544.pdf; https://doi.org/10.28945/3527

[9] Drolia, M., Sifaki, E., Papadakis, S., \& Kalogiannakis, M. (2020). An overview of mobile learning for refugee students: Juxtaposing refugee needs with mobile applications' characteristics. Challenges, 11(2), 1-14. https://doi.org/10.3390/challe11020031

[10] Buckler, T. (2012). Is there an app for that? Developing an evaluation rubric for apps for use with adults with special needs. The Journal of BSN Honors Research, 5(1), 19-32.

[11] Weng, P-L. (2015). Developing an app evaluation rubric for practitioners in special education. Journal of Special Education Technology, 30(1), 43-58. https://doi. org/10.1177/016264341503000104

[12] Papadakis, S., Vaiopoulou, J., Kalogiannakis, M., \& Stamovlasis, D. (2020). Developing and exploring an evaluation tool for educational apps (ETEA) targeting kindergarten children. Challenges, 12(10), 1-10. https://doi.org/10.3390/su12104201

[13] Vaiopoulou, J., Papadakis, S., Sifaki, E., Stamovlasis, \& Kalogiannakis, M. (2021). Parents' perceptions of educational apps use for kindergarten children: Development and validation of a new instrument (PEAU-p) and exploration of parents' profiles. Challenges, 11(6), 1-17. https://doi.org/10.3390/bs11060082

[14] Koh, J. H. L., \& Divarahan, S. (2011). Developing pre-service teachers' technology integration expertise through the TPACK-developing instructional model. Journal Educational Computing Research, 44(1), 35-58. https://doi.org/10.2190/EC.44.1.c

[15] Turgut, Y. (2017). Tracing pre-service English language teachers' perceived TPACK in sophomore, junior, and senior levels. Cogent Education, 4(1), 1-20. https://doi.org/10.1080/ 2331186X.2017.1368612

[16] Yeh, H-C., \& Tseng, S-S. (2019). Using the ADDIE Model to nurture the development of teachers' CALL professional knowledge. International Forum of Educational Technology \& Society, 22(3), 88-100.

[17] Ersanli, C. Y. (2016). Improving technological pedagogical content knowledge (TPACK) of Pre-Service English language teachers. International Education Studies, 9(5), 18-27. https://doi.org/10.5539/ies.v9n5p18

[18] Mishra, P., \& Koehler, M. J. (2006). Technological pedagogical content knowledge: A framework for teacher knowledge. Teachers College Record, 108(6), 1017-1054. http:// dx.doi.org/10.1111/j.1467-9620.2006.00684.x

[19] Shulman, L. S. (1986). Those who understand: Knowledge growth in teaching. Educational Researcher, 15(2), 4-14. http://www.jstor.org/stable/1175860; https://doi.org/ 10.3102/0013189X015002004

[20] Shulman, L. S. (1987). Knowledge and teaching: Foundations of the new reform. Harvard Educational Review, 57(1), 1-23. https://doi.org/10.17763/haer.57.1.j463w79r56455411 
[21] Angeli, C., \& Valanides, N. (2009). Epistemological and methodological issues for the conceptualization, development, and assessment of ICT-TPCK: Advances in technological pedagogical content knowledge (TPCK). Computers \& Education, 52(1), 154-168. https://doi.org/10.1016/j.compedu.2008.07.006

[22] Brantley-Dias, L., \& Ertmer, P. A. (2013). Goldilocks and TPACK. Journal of Research on Technology in Education, 46(2), 103-128. https://doi.org/10.1080/15391523.2013.10782615

[23] Cox, S., \& Graham, C. (2009). Diagramming TPACK in practice: Using an elaborated model of the TPACK framework to analyze and depict teacher knowledge. TechTrends, 53(5), 60-69. https://doi.org/10.1007/s11528-009-0327-1

[24] Kimmons, R. (2015). Examining TPACK's theoretical future. Journal of Technology and Teacher Education, 23(1), 53-77.

[25] Jaipal-Jamani, K., \& Figg, C. (2015). The framework of TPACK-in-practice: Designing content-centric technology professional learning contexts to develop teacher knowledge of technology-enhanced teaching (TPACK). In C. Angeli., \& V. Nicos (Eds.), Technological pedagogical content knowledge: Exploring, developing, and assessing TPCK, (pp. 137-163). Springer. https://doi.org/10.1007/978-1-4899-8080-9 7

[26] Santos, J. M., \& Casro, R. D. R. (2021). Technological pedagogical content knowledge (TPACK) in action: Application of learning in the classroom by pre-service teachers (PST). Social Sciences \& Humanities Open, 3, 1-8. https://doi.org/10.1016/j.ssaho.2021.100110

[27] Nordin, H., Davis, N., \& Tengku Ariffin, T. F. (2013). A case study of secondary pre-service teachers' technological pedagogical and content knowledge mastery level. Procedia-Social and Behavioral Sciences, 103, 1-9. https://doi.org/10.1016/j.sbspro.2013.10.300

[28] Solak, E., \& Çakır, R. (2014). Examining preservice EFL teachers' TPACK competencies in Turkey (EJ1033263). ERIC. https://files.eric.ed.gov/fulltext/EJ1033263.pdf

[29] Howard, S. K., Tondeur, J., Siddiq, F., \& Scherer, R. (2020). Ready, set, go! Profiling teachers' readiness for online teaching in secondary education. Technology, Pedagogy and Education, 1-18. https://doi.org/10.1080/1475939X.2020.1839543

[30] Wen, K. Y. K., \& Tan, K. H. (2020). ESL teachers' intention in adopting online educational technologies during covid-19 pandemic. Journal of Education and e-Learning Research, 7(4), 387-394. https://doi.org/10.20448/journal.509.2020.74.387.394

[31] Cancino, M., \& Panes, J. (2021). The impact of Google Translate on L2 writing quality measures: Evidence from Chilean EFL high school learners. System, 98, 1-11. https://doi.org/ 10.1016/j.system.2021.102464

[32] Wang, S., \& Lee, C-I. (2020). Exploring the effectiveness of hypermedia glosses for second language reading. The Journal of ASIA TEFL, 17(4), 1284-1293. http://dx.doi.org/10.18823/ asiatefl.2020.17.4.8.1284

[33] Zhao, X., Wang, Y., Liu, Y., Xu, Y., Meng, Y., \& Guo, L. (2019). Multimedia based teaching platform for English listening in universities. International Journal of Emerging Technologies in Learning, 14(4), 160-168. https://doi.org/10.3991/ijet.v14.i04.9690

[34] Sun, Z., Lin, C-H., You, J., Shen, H. J., Qi, S., \& Luo, L. (2017). Improving the English-speaking skills of young learners through mobile social networking. Computer Assisted Language Learning, 30(3-4), 304-324. https://doi.org/10.1080/09588221.2017.1308384

[35] Yeh, H-C., Tseng, S-S., \& Chen, Y-S. (2019). Using online peer feedback through blogs to promote speaking performance. International Forum of Educational Technology \& Society, 22(1), 1-14.

[36] Purgina, M., Mozgovoy, M., \& Blake, J. (2020). WordBricks: Mobile technology and visual grammar formalism for gamification of natural language grammar acquisition. Journal of Educational Computing Research, 58(1), 126-159. https://doi.org/10.1177/0735633119833010

[37] Serfaty, J., \& Serrano, R. (2020). Examining the potential of digital flashcards to facilitate independent grammar learning. System, 94, 1-14. https://doi.org/10.1016/j.system.2020.102342 
[38] Alfadil, M. (2020). Effectiveness of virtual reality game in foreign language vocabulary acquisition. Computers \& Education, 153, 1-13. https://doi.org/10.1016/j.compedu.2020.103893

[39] Octaberlina, L. R., \& Rofiki, I. (2021). Using online game for Indonesian EFL learners to enrich vocabulary. International Journal of Interactive Mobile Technologies, 15(1), 168-183. https://doi.org/10.3991/ijim.v15i01.17513

[40] Huang, Y-Y., Liu, C-C., Wang, Y., Tsai, C-C., \& Lin, H-M. (2017). Student engagement in long-term collaborative EFL storytelling activities: An analysis of learners with English proficiency differences. International Forum of Educational Technology \& Society, 20(3), 95-109.

[41] Han, Y., \& Yin, W. (2020). The effect of multimedia teaching platform based on virtual technology on students' English learning motivation. International Journal of Electrical Engineering \& Education, 1-16. https://doi.org/10.1177/0020720920988495

[42] Xu, S., Li, X., \& Yang, X. (2021). Multilateral interactive teaching model for improving foreign language learners' autonomous learning ability by using multimedia network technology. International Journal of Electrical Engineering \& Education, 1-13. https://doi. org/10.1177/0020720920986077

[43] Hung, H-C., \& Young, S. S-C. (2015). An investigation of game-embedded handheld devices to enhance English learning. Journal of Educational Computing Research, 52(4), 548-567. https://doi.org/10.1177/0735633115571922

[44] Lee, J-H., \& Kim, H. (2017). Implementation of SMART teaching 3.0: Mobile-based self-directed EFL teacher professional development. The Journal of ASIA TEFL, 13(4), 331-346. http://dx.doi.org/10.18823/asiatefl.2016.13.4.6.331

[45] Zainuddin, Z., Habiburrahim, Muluk, S., \& Keumala, C. M. (2019). How do students become self-directed learners in the EFL flipped-class pedagogy? A study in higher education. Indonesian Journal of Applied Linguistics, 8(3), 678-690. https://doi.org/10.17509/ ijal.v8i3.15270

[46] Paniagua, A., \& Istance, D. (2018). Teachers as designers of learning environment: The important of innovative pedagogies. OECD Publishing. http://dx.doi.org/10.1787/ 9789264085374-en

[47] Oyedatun, T. D. (2020). Sudden change of pedagogy in education driven by COVID-19: Perspectives and evaluation from a developing country. Research in Globalization, 2, 1-5. https://doi.org/10.1016/j.resglo.2020.100029

[48] Cutri, R. M., Mena, J., \& Whiting, E. F. (2020). Faculty readiness for online crisis teaching: Transitioning to online teaching during the COVID-19 pandemic. European Journal of Teacher Education, 43(4), 523-541. https://doi.org/10.1080/02619768.2020.1815702

[49] Yin, R. K. (2018). Case study research and application; Design and methods (6th ed.). SAGE Publications, Inc.

[50] Graurer, K. (2012). A case for case study research in education. In Klein, S. R. (Ed.), Action Research Methods; Plain and simple (pp. 69-80). Palgrave MacMillan. https://doi. org/10.1057/9781137046635 4

[51] Hamilton, L., \& Corbett-Whittier, C. (2013). Using case study in education research. SAGE Publications, Inc. https://doi.org/10.4135/9781473913851

[52] Creswell, J. W., \& Creswell, J. D. (2018). Research design: Qualitative, quantitative and mixed methods approaches (5th ed.). SAGE Publications, Inc.

[53] Creswell, J. W., \& Poth, C. N. (2018). Qualitative inquiry \& research design: Choosing among five approaches (4th ed.). SAGE Publications, Inc.

[54] Miles, M. B., Huberman, A. M., \& Saldaña, J. (2014). Qualitative data analysis: A methods sourcebook (3rd ed.). SAGE Publications, Inc. 
[55] Bona, C. (2017, November 22-23). The use of Spotify to increase English listening skills [Paper presentation]. The Tenth International Conference on Applied Linguistics (CONAPLIN 10) and The Second English Language Teaching and Technology (ELT-Tech 2), Bandung, Indonesia.

[56] Bal, M. (2018). Reading and writing experiences of middle school students in the digital age: Wattpad sample. International Journal of Education \& Literacy Studies, 6(2), 89-100. http://dx.doi.org/10.7575/aiac.ijels.v.6n.2p.89

[57] Reid, C. (2016). Wattpad grows from reading site to multiplatform entertainment venue. Publishers Weekly, 263(50), 10-11.

[58] Papadakis, S., Kalogiannakis, M., \& Zaranis, N. (2021). Teaching mathematics with mobile devices and the Realistic Mathematical Education (RME) approach in kindergarten. Advances in Mobile Learning Educational Research, 1(1), 5-18. https://doi.org/10.25082/ AMLER.2021.01.002

[59] Papadakis, S. (2021). The impact of coding apps to support young children in computational thinking and computational fluency: A literature review. Frontiers in Education, 6(657895), 1-12. https://doi.org/10.3389/feduc.2021.657895

\section{Authors}

Agatha Lisa is a doctoral candidate in English language education at the Postgraduate Program, Universitas Negeri Semarang (UNNES), Semarang, Indonesia. She is an active member of iTELL (Indonesia Technology Enhanced Language Learning). She actively gives workshops on digital educational tools for secondary English teachers in Indonesia. Email: agathalisa9@gmail.com. Orcid ID: https://orcid. org/0000-0002-7475-3027

Abdurrachman Faridi is a professor and lecturer in the Postgraduate Program of English Language Education, Universitas Negeri Semarang (UNNES), Semarang, Indonesia. Email: pakdur@mail.unnes.ac.id, Scopus ID: 57201503215.

Dwi Anggani Linggar Bharati is an associate professor and lecturer in the Postgraduate Program of English Language Education, Universitas Negeri Semarang (UNNES), Semarang, Indonesia. Email: dwi_anggani@yahoo.com, Scopus ID: 57209469842.

Mursid Saleh is a professor and lecturer in the Postgraduate Program of English Language Education, Universitas Negeri Semarang (UNNES), Semarang, Indonesia. Email: mursids@hotmail.com, Scopus ID: 57208058655. Orcid ID: https://orcid. org/0000-0002-4049-5322

Article submitted 2021-04-21. Resubmitted 2021-07-06. Final acceptance 2021-07-07. Final version published as submitted by the authors. 